\title{
Transaction attributes and adoption of hybrid governance in the Brazilian cattle market
}

\author{
M. de Mello Brandão Vinholis ${ }^{{ }^{*}}$, H. Meirelles de Souza Filho ${ }^{2}$, M.J. Carrer ${ }^{2}$ and F.R. Chaddad ${ }^{3}$ \\ ${ }^{1}$ Brazilian Agricultural Research Corporation (Embrapa), Rod. Washington Luiz, km 234, 13560-970, São Carlos, SP, Brazil; \\ ${ }^{2}$ Department of Production Engineering, Federal University of Sao Carlos, Rod. Washington Luiz, km 235, 13565-905, São Carlos, \\ SP, Brazil; ${ }^{3}$ Division of Applied Social Sciences, University of Missouri, 125B Mumford Hall, Columbia, MO 65211-6200, USA; \\ marcela.vinholis@embrapa.br
}

RESEARCH ARTICLE

\begin{abstract}
A transaction cost economics framework was used to test hypotheses on the alignment of transaction attributes and governance structures using data from a sample of 84 beef cattle farms in Brazil. A bivariate logit model was employed. It was found that the adoption of traceability and its certification and highly capital-intensive production systems, used here as proxies for asset specificity, plays a positive role in the choice of hybrid forms of governance.
\end{abstract}

Keywords: livestock, contracts, transaction cost economics

Copyright: ${ }^{\oplus} 2014$ M. de Mello Brandão Vinholis et al. This is an open-access article distributed under the terms of the Creative Commons Attribution License, which permits unrestricted use, distribution, and reproduction in any medium, provided the original author and source are credited.

\section{Introduction}

Cases of severe food contamination and the mad cow crisis of the 1990s have driven interventionist policies and many private regulations aimed at ensuring food quality and safety (Fulponi, 2006; Hobbs, 2004; Krieger and Schiefer, 2007; Trienekens and Zuurbier, 2008). The institutional environment has changed with the introduction of new technical regulations and other food safety mechanisms. These changes have led to an increase in investment in specific assets associated with the need for better coordination, alignment of strategies and redesign of contractual arrangements between agents of the production chain. As a result, different strategies and contractual arrangements designed for different markets now coexist (Mondelli and Zylbersztajn, 2008a; Zylbersztajn and Machado Filho, 2003). The spot market is no longer the only form of governance for transactions between cattle farmers and meat processing plants in Brazil. Forward contracts and relational contracts - which are classified as hybrid forms of governance, according to the heuristic model developed by Williamson (1985) - are now used in transactions between meat processing plants and cattle farmers in Brazil.
Transaction cost economics (TCE) is a helpful theoretical approach for understanding the reasons behind the appearance and adaptation of different organizational arrangements in agriculture. It supports the proposition that modes of governance are aligned with transaction attributes, such as: specificity of the assets involved, the uncertainty to which the transactions are subject and the frequency with which the transactions are conducted. This alignment minimizes transaction costs (Williamson, 1985, 1991). The objective of this article is to identify whether these attributes determine the adoption of hybrid forms in transactions of finished cattle between farmers and slaughterhouses in the Brazilian state of São Paulo. Besides its academic importance, this study has management implications. Coordination has become a strategic issue for accessing new market opportunities for the Brazilian beef industry, which exports $18 \%$ of its production (MAPA, 2013). The results can assist both farmers and slaughterhouses in effective organizational design for specific markets. For the investigation, data were collected from a sample of 84 producers located in the state of São Paulo, which were analysed using a dichotomous choice model, known as the logit model. The following sections present the theoretical framework, the description of governance structures in finished cattle transactions in Brazil, the hypotheses 
regarding the determinants for adopting hybrid forms of governance, the methodology and the results.

\section{Theoretical framework}

TCE was used to support the analysis presented in this article. This approach makes an important contribution to the research on inter-organizational arrangements within the supply chain (Halldorsson et al., 2007) and has been used in empirical studies that focus on transactions between agents of supply chains (Boger et al., 2001; Hobbs and Young, 2000). In contrast to neoclassical microeconomic theory, TCE assumes that markets do not work exclusively through the price mechanism. There are costs involved in using the price mechanism that justify the existence of other modes of organizing economic transactions (Coase, 1937). The choice of the coordination mechanism depends on the cost of discovering current market prices (collection of information), the cost of negotiating and drafting contracts, and the cost of ensuring compliance with the terms of the contract. These costs are called transaction costs.

Agents should adopt governance structures that enable them to reduce transaction costs (North, 1992). There are changes to the institutional, technological or economic environment for which the pricing system can convey all the relevant information and are sufficient to induce the adaptation of the agents. Other changes require coordinated responses between the agents and involve more complex contractual arrangements (Williamson, 1991). Williamson (1985) identified three basic forms of coordinating transactions, also called governance structures:

- Spot market: market exchange is an adapted form of nonspecific transaction, where there is no continuity in the relationship. In this mechanism, the evaluation of the relationship by the parties is based on their own experience. It is the structure that best approximates the neoclassical theoretical framework of pure competition.

- Hybrid forms: given the specificity of the assets and the recurring nature of the transactions, credible commitments are created and relationships of trust can be built. Formal and informal contracts work as a framework, since the agents are inclined to establish and comply with their clauses.

- Vertical integration: coordination necessary for regular transactions and in the presence of highly specific assets. In this structure, the transactions between agents are brought into the hierarchy of the firm.

The emphasis placed by Williamson (1985) on the analysis of coordination mechanisms uncovered hybrid structures, which lie somewhere between the market and the hierarchy.
Ménard (2004) stressed the need to develop a theory that explains these modes of organization, in which the agents are independent of each other, but work together in some type of business. In arrangements of this type, the agents can share technological knowledge, capital, products or services, without, however, internalizing the activities within a single firm. The influence of price mechanisms is lower than in the spot market. Regardless of its format, the coordination of activities is based on cooperation between the parties and in the sharing of relevant decisions, such as investment decisions. This cooperation creates an environment that encourages the joint pursuit of better performance and greater profitability for the whole. However, a poor distribution of tasks and gains can easily generate conflict, which can destabilize and weaken the arrangement.

TCE evaluates organizational efficiency based on alignment between transaction attributes and form of governance, on the assumption that the agents have limited reasoning ability and are opportunists. The fundamental attributes of the transactions are: (1) the specificity of the assets involved; (2) uncertainty to which the transactions are subject; and (3) the frequency with which the transactions are conducted.

Specific assets have particular purposes which cannot be employed in any other way without a considerable loss of value (Williamson, 1991). Therefore, the specificity of the assets is not the sole determinant, but it is particularly important in adopting more cooperative forms of governance (Klein, 2008; Macher and Richman, 2008; Masten, 2000), which are associated with bilateral dependence (Zylbersztajn, 1995). The greater the specificity of the assets involved in the production of a good, the stronger the incentives to adopt a hybrid form of governance or even vertical integration. The specificity of an asset is classified into six types: (1) site specificity, when the use of an asset in a certain transaction generates savings in shipping and storage costs; (2) physical specificity, when the assets are designed for a specific purpose (e.g. specific inputs for the production of a certain product); (3) human specificity, which is based on the idea of 'learning by doing'; (4) dedicated assets, when specific investments are made for a particular purpose, for a certain client; (5) brand name capital; and (6) temporal specificity (Williamson, 1989).

In agriculture, the specificities most important to the assets are site, physical and temporal. This last one, in general, is the result of perishability and climactic conditions that influence the quantity and quality of agricultural products (Raynaud et al., 2009). Another type of specificity comprises investments in knowledge, processes and equipment with a view to reducing variability in product quality. A number 
of empirical studies in agriculture bear out the connection between asset specificity and tight vertical coordination. These include: Mondelli and Klein's (2014) analysis of the use of external equity finance by firms in agricultural production; Guo and Jolly's (2008) evaluation of the relationship between contractual arrangements and their enforcement in Chinese agriculture; Mello and Paulillo's (2010) analysis of the organizational arrangements between farmers and processors in the Brazilian citrus industry; Banterle and Stranieri's (2008) investigation on the effects of voluntary traceability on vertical relationships within the beef chain in Italy; Mondelli and Zylbersztajn's (2008b) study of contractual arrangements among Uruguayan beef producers and processors; Zylbersztajn and Miele's (2005) assessment of the contracts between wineries and grape growers in Brazil; Martinez's (2002) comparison of vertical coordination in the U.S. poultry, egg and pork industries; and Globerman and Schwindt's (1986) investigation of determinants of vertical integration in the Canadian forest products sector.

Uncertainty introduces disturbances that affect the exchange process. Uncertainty can be both primary - when it is the result of random behaviour and unpredictable changes and secondary - when derived from the fact that decision makers are unaware of the intentions of the other party (Williamson, 1985). The degree of inherent uncertainty in a transaction is another important determinant of the type of governance adopted. In fact, transactions that occur in a predictable environment are less complex than transactions carried out in a more uncertain environment and, therefore, more susceptible to unexpected changes. The greater the chances of unpredictable changes, the greater the need for the introduction of adaptation clauses in a contract, the greater possibility of there being gaps and the greater the potential for opportunistic actions, which would thus raise transaction costs. A highly uncertain environment can therefore lead to the adoption of a hierarchical form of governance in a transaction.

The frequency with which the relationship between the parties is established is another dimension of the transaction. This attribute is important because the more often a transaction is repeated, the greater the possibility of diluting the costs of adopting a complex governance mechanism. In this case, a reputation based upon reciprocity between the parties can be built.

Based on an alignment between the attributes of the transaction (asset specificity, uncertainty and frequency) and the governance structure adopted, an evaluation of the organizational efficiency becomes possible. A poorly chosen governance structure or one poorly adapted to the transaction leads to coordination difficulties.

\section{Governance structures in finished cattle transactions}

The finished cattle market in Brazil has been traditionally characterized by a predominance of spot market transactions. The Brazilian cattle farmer is a price taker in the market and, generally, trades the animals on the spot market, where there is no commitment to a continued relationship (Pigatto, 2001; Vinholis, 2001). Pitelli (2004) verified that most acquisitions of finished cattle for slaughter occurred through the spot market. However, verticalization of production has grown due to the establishment of farms belonging to large meat processing companies. By internalizing part of the production process, the meat processing company reduces information problems and the costs of measuring characteristics of the experiential goods, in addition to considerably increasing control over the quality of the raw material, thus reducing transaction costs.

More recently, new cattle commercialization methods have emerged as a way of serving market niches. As Brazilian beef has gained market share abroad, coordination has become a strategic issue of major importance for this industry. Accordingly, the use of forward contracts between cattle farmers and meat processing plants has also risen (Carrer et al., 2011). For the cattle farmer, a forward contract allows technical and financial scheduling of production and mitigates the uncertainty from the specificity of the asset and the risk of price, ensuring the sale at a known price and encouraging investments to improve the production process with possible gains in quality and productivity. For the meat processing plants, the forward contract ensures a supply of raw material with pre-established standards of quality and enables better planning and control of supply and production with consequent gains in competitiveness and coordination. Table 1 summarizes the structures of governance found in the beef cattle supply chain in Brazil.

\section{Hypotheses}

The objective of this section is to present the hypotheses for the role of asset specificity, frequency of transactions and uncertainty in the adoption of hybrid forms of governance in the finished cattle market. These hypotheses are presented in three subsections, and are associated with the influence exercised by these three characteristics of transaction, according to the theoretical framework presented. 
Table 1. Governance structures identified in finished cattle transactions in Brazil.

Governance structure Description

Spot market

Relational contract (hybrid form)

Forward contract (hybrid form)

Vertical integration

Both meat processing company and cattle farmer are separate legal entities. There is no commitment to continue the relationship with a particular buyer. The negotiation of the price and the number of animals occurs sometime near the delivery date. There is no interdependence between the parties. Due to the trust established between the parties, a credible informal agreement (Hendrikse, 2003) can be negotiated between them. Both are separate legal entities. The scale of the delivery of the animals to the slaughterhouse units is established before the fattening phase on farms, with the number of animals and the delivery date pre-established. Price is determined by market quotation on the delivery date for the animals, and is established based on the ESALQ/BM\&F index. Payment of a premium for quality and traceability can also be agreed upon. Reputation is responsible for mitigating opportunistic actions.

This is a formal contract between the cattle farmer and the meat processing company, which maintain their status as separate legal entities. Pre-established in the contract are: future delivery date of the animals, number, weight, age, sex, in addition to the price per carcass weight in arrobas ( 1 arroba $=15$ $\mathrm{kg})$. The ESALQ/BM\& $\mathrm{F}^{1}$ index is used for this last calculation, to which a premium can be added. This premium is determined depending on the demand and supply for quality and/or traceable animals. There are also contractual fines if one of the parties breaches the terms of the contract (Carrer et al., 2014).

Both meat processing plant and cattle farmer are part of the same legal entity. The transaction is internalized in the company. The meat processing plant has its own confinement farms for the production of animals that meet the specific characteristics required by certain market segments.

${ }^{1}$ ESALQ = Escola Superior de Agricultura Luiz de Queiroz (Luiz de Queiroz College of Agriculture); BM\&F = Bolsa de Mercadorias e Futuro (The Commodities \& Futures Exchange).

\section{Specificity of assets}

The specificity of the assets used in the production of finished cattle in Brazil has increased due to the adoption of highly capital-intensive production systems, as well as the adoption of traceability systems. In the Central-West region of the country, more intensive production systems have spread due to deficient infrastructure that restricts access to cheaper land on the agricultural frontier, as well as growing restrictions imposed by environmental legislation on the use of these lands (Correa et al., 2000). These barriers restrict the adoption of systems based on the use of large tracts of pasture and low density of animals per hectare of land. In the Southeast region, particularly in São Paulo, rising land prices and competition from other more profitable agricultural crops have contributed to the spread of more capital-intensive production systems (Souza Filho et al., 2010). However, intensive production systems do allow for the raising of animals whose meat has the tenderness and flavour that are valued by some segments of the market, for example, barbecue restaurants and supermarkets located in high income areas and some export markets. Obtaining these characteristics in the final product depends on a set of factors, which include the animal's genetics, the production system and industrial processes. Cattle farmers who rear animals with these characteristics, in general, adopt fattening systems in confinement and produce a superior product.

The intensification of the use of inputs increases the risk and complexity of the production system. The cost structure is altered and requires greater disbursement of financial resources for the adoption of the technological package. This situation requires stricter production management, without which the profitability of the system would be compromised (Correa et al., 2000). Precise control of inventory and production costs determines the success of the more intensive production systems, which require more highly skilled labour. In addition to investment in the training of employees, the highly intensive production system requires specific physical investments, for example, the construction of silos, pens or rotational grazing infrastructure to fatten the animals and electronic scales. Strict control over weight gain and time for slaughter of the animals is key to the success of the activity. The marginal cost increases at a higher rate when the bovine reaches its optimum weight. Generally, the metabolism of a bovine with 270 kilos of 
weight, or more, shifts to deposition of fat at the expense of protein deposition (Owens et al., 1993), resulting in loss of economic efficiency. In this case, the deposition of fat tissue (high fat) is 2.5 times more energy-inefficient than the deposition of muscle tissue (protein rich), as adipose tissue and muscle tissue have respectively about 10 and $78 \%$ water in their compositions. Moreover, the abdominal adipose tissue is removed during the slaughter and its weight is discounted in the payment received by the farmer. Therefore, more capital-intensive livestock production systems are characterized by greater physical and temporal specificity of the assets, when compared with rearing systems based on the extensive use of land.

The above temporal and physical specificity of the assets, associated with price risk, requires more planning and involves the adoption of management technologies and associated information technologies. This is the case for famers who are capable of rearing livestock to produce beef accepted by the European Union (EU). The diffusion of new legal rules and certification systems related to food safety and food quality in international trade is increasingly determining market access in high value chains (Kariuki $e t$ al., 2012). The EU has demanded traceability as a condition for market access. This demand has had an impact on the national regulatory environment for food safety. In 2002, the Brazilian System of Identification and Certification of Bovine and Bubaline Origin (SISBOV) was created. In 2011, the SISBOV certification was a necessary, but not sufficient condition to be allowed to export to the EU market. The farm also had to acquire TRACES (Trade Control and Expert System) certification. TRACES is a veterinary health network created by the EU which notifies, certifies and monitors trade in animals and animal products. However, the level of adoption of SISBOV certification is still low among Brazilian farms. A small number of farms have adopted this certification, but technological heterogeneity persists in bovine livestock production in Brazil.

Certification of the rural property in SISBOV assumes the adoption of operational and management technology for food safety in livestock rearing. Specific investments in operational training, documentation and auditing of the traceability system are incorporated. Investment in training is carried out, generally, through the 'learning by doing' approach. In addition to this initial cost, the certification process incurs other costs, including inspections and audits of the system and a fee per animal to be entered in the system. The incorporation of traceability prompts the adoption of information technology, such as electronic ear tags, optical readers and software for managing and issuing inventory reports and forms. These investments therefore can increase the specificity of the assets, considering the human, physical and dedicated specificities.

On the other hand, the cattle farmer that invests in SISBOV certification and in the necessary assets expects that he will receive a premium above the market price for these animals. According to Kariuki et al. (2012), the compliance with third-party certification schemes might be motivated by higher or more stable product prices. However, this premium price varies according to the supply and demand of animals traced according to this certification. Therefore, there is uncertainty about their worth. In addition to this uncertainty, and the economic risk associated with it, there are also significant uncertainties regarding the institutional environment. These uncertainties arise from the frequent, often unexpected, changes in regulations that determine the 'rules of the game' for the adoption of the traceability system and certification.

TCE assumes the agents involved in the transaction will behave in an opportunistic manner. The possibility of postcontractual opportunism associated with investments in specific assets leads the agents to anticipate and mitigate post-contractual problems, by drafting precautionary measures as a way of ensuring appropriate returns on the investments made. Zylbersztajn (2005) cites as an example the possibility of earning quasi-rents when a cattle farmer, in order to meet the demand of a meat processing plant, makes investments in assets with a level of specificity above zero. A price $P$ is determined or expected before investments are made. In the absence of safeguards, the cattle farmer will be exposed to the possibility of opportunistic behaviour; i.e. there is a risk in receiving - a posteriori - a lower price than that agreed to or expected, that covers their fixed costs, but does not provide the desired return. If this occurs, the difference is settled by the meat processing plant. Formal and informal institutional arrangements, supported by a long-term relationship, are mechanisms designed to ensure the expected return. In the case of beef cattle, one of the ways of safeguarding and mitigating uncertainty about receiving premiums is through a forward contract with the meat processing plant. This mechanism has grown in importance in the industry and can include a clause relating to a premium for a traced and certified animal.

In view of the above, the joint adoption of capital-intensive production systems and SISBOV certification implies investments in specific assets and, therefore, the need to adopt hybrid forms of commercialization. In this sense, the following hypothesis can be formulated: 
H1: The joint adoption of capital-intensive production systems and SISBOV certification increases the specificity of the assets and, therefore, the probability of the adoption of hybrid forms of commercialization for finished cattle.

\section{Frequency}

The attribute frequency is not dealt with directly in the model by Williamson, but its effects are related to reputation. On the one hand, recurring transactions enable the development of reputation and a relationship of greater trust between the agents (Rodrigues and Moraes, 2005). On the other hand, the more transactions there are, the greater the need for contractual safeguards to deal with unexpected events resulting from contractual incompleteness and opportunistic actions (Williamson, 1985). Therefore, a positive relation between the frequency of the transaction and the adoption of closer contractual arrangements is expected.

In the Brazilian beef cattle market, transactions between cattle farmers and meat processing plants are recurrent. Informal relationships, based on trust between the cattle farmer and the purchaser, or the broker for the meat processing company, predominate (Pitelli, 2004). To meet the requirements of some segments of the beef cattle market, the meat processing plant selects certain cattle farmers. For this selection, information obtained from the history of the relationship with the supplying cattle farmers is used. In this way, the frequency of the transactions between the cattle farmers and the meat processing plant can be empirically measured by the number of years the trade relationship has been maintained.

H2: The higher the transaction frequency between the parties, the greater the probability that hybrid forms of commercialization for finished cattle will be adopted.

\section{Uncertainty}

Uncertainty is another transaction dimension in the model by Williamson (1985). The principal uncertainties in the production and commercialization of finished cattle are related to quality and price. The quality of the beef is an attribute made up of various factors, including the genetics of the cattle, age at slaughter and the production system. When the meat processing plant wants to reduce uncertainties related to the quality attributes of finished cattle, it can rely on information obtained from the history of the relationship with the cattle farmers. In this way, the meat processing plant will select those cattle farmers that, with greater frequency, deliver animals that have the desired characteristics, enabling them to establish relational contracts.

Another uncertainty in the transactions between the cattle farmer and meat processing plants comes from the variation in finished cattle prices, as well as the variation in prices for 9 and 18-month-old calves for fattening. The relationship between these two prices establishes the cattle/calf exchange ratio, which is an important economic indicator for cattle farmers that specialize in the fattening phase of cattle production. ${ }^{1}$ For Arieira et al. (2007), the price of the calf for fattening represents an important part of the production costs in systems dedicated solely to the fattening of animals. Calves for fattening represent around $70 \%$ of the operational expenses of confinement. Cattle farmers that specialize only in the fattening phase use the spot market as a form of governance to meet their needs for calves. In this case, profitability depends largely on the exchange ratio, which varies according to the behaviour of either the finished cattle market or the spot market for calves. With a very tight profit margin in these production systems, small variations in this relationship can significantly affect the indicators of economic viability. However, there are producers of finished cattle that internalize, totally or partially, their needs for calves for fattening. In this last case, verticalization allows them to offset the impact of the changes in spot market prices for calves. In fact, their costs are associated with their own management efficiency and the prices of necessary inputs for the creation and maintenance of pastures. Therefore, it is assumed that cattle farmers who are more dependent on the supply of third parties for their calf needs are more subject to abrupt changes in their profit margins than cattle farmers who adopt hierarchy as their form of governance to meet their needs for calves.

The present article will therefore use the percentage of animals (backgrounding cattle) acquired from third parties for the fattening phase as a proxy for the measurement of uncertainty. It is assumed that uncertainty increases as the percentage of backgrounding cattle acquired from third parties rises.

\footnotetext{
${ }^{1}$ In Brazil, the cattle production cycle is traditionally composed of three production phases: pre-weaning, post-weaning and finishing. These phases can be carried out separately on different farms or on the same farm. The pre-weaning phase requires the largest amount of land per animal. Therefore this phase is normally carried out in regions where the land cost is lower. The finishing phase, on the other hand, can be more capital intensive and requires less area per animal; it is therefore economically viable in regions where the cost of land is higher.
} 
H3: The higher the uncertainty, the higher the probability that a hybrid form of commercialization of finished cattle will be adopted.

\section{Method}

A survey questionnaire was used with a sample of farmers in order to collect information on transactions, adoption of certifications, production system, size of the farm, relationship with the meat processing plant, income and calf purchase. Interviews were carried out personally with farm owners from February to August 2011, the average interview lasting two hours. Cross-section data was collected on 84 farms located in the livestock production region of the state of São Paulo, from which 32 certified farms were randomly selected from a set of 137 farms certified to export beef to the EU, and 52 non-certified nearby farms randomly selected from a list of non-certified farms obtained from records of farmers associations and rural unions. Three criteria were used in the selection: certified and non-certified farms must be in the same production region; livestock must be the major economic activity on the farm; and the farm must perform the fattening phase of cattle rearing (though not exclusively). These criteria eliminated two farms from the total of 86 initially visited. As stated in the SISBOV regulation, the cattle must stay for a minimum of 90 days in a zone qualified for export and 40 days in the last certified farm prior to slaughter. Thus, the great incentive for certification adoption is on the finishing phase of cattle rearing. This sampling technique lowers the cost of the survey and reduces the scope for discriminating farms in terms of their environmental characteristics (soil types, topography, water supply and climate).

The analysis of the survey data was performed with the estimation of a discrete choice logit model. This model has also been used in other empirical analyses on the alignment between transaction attributes and governance structures (Mello and Paulillo, 2010; Mondelli and Zylbersztajn, 2008a). The variable to be 'explained' is the dichotomous choice: 1 = adoption of hybrid forms (relational contracts and forward contracts, as stated in Table 1); 0 = adoption of spot market.

In making the decision on whether or not to adopt the hybrid forms, it may be assumed that the farmer weighs the marginal advantages and disadvantages of the arrangement. As the parameters of this decision are not readily observable, for each farmer i we can define a latent variable, $\mathrm{y}^{*}$, as:

$y_{i}^{*}=\beta^{\prime} X_{i}+u_{i} \quad i=1, \ldots, N$ where X denotes a set of explanatory variables. The observed pattern of governance choice can be described by a dummy variable, $y$, such that $\mathrm{y}_{\mathrm{i}}=1$ if farmer i adopts hybrid form, $y_{i}=0$ if he/she works in the spot market. These observed values of $\mathrm{y}$ are related to $\mathrm{y}^{*}$ as follows:

$y_{i}=1 \quad$ if $y_{i}^{*}>0$

$y_{i}=0 \quad$ otherwise

and

$\operatorname{Pr}\left(y_{i}=1\right)=\operatorname{Pr}\left(y_{i}^{*}>0\right)=\operatorname{Pr}\left(u_{i}>-\beta^{\prime} X_{i}\right)=1-F\left(-\beta^{\prime} X_{i}\right)=F\left(\beta^{\prime} X_{i}\right)$

where $\mathrm{F}$ is the cumulative distribution function for $\mathrm{u}$ and a symmetric distribution is assumed. Using maximum likelihood procedures, estimates of the $\beta$ parameters can be obtained. For the logit model, a logistic cumulative distribution function is assumed,

$\operatorname{Pr}\left(y_{i}=1\right)=\frac{e^{\beta X}}{1+e^{\beta X}}=\Lambda\left(\beta^{\prime} X\right)$

where $\Lambda$ denotes the logistic cumulative distribution function.

Here, the 'odds ratios' (or $e^{\beta}$ ) rather than the $\beta$ coefficients themselves are presented. The interpretation is that as the explanatory variables change, the probability of farmers adopting the hybrid forms changes by that factor. In other words, variables with an odds ratio greater than unity would increase the probability of use of hybrid forms, while those with a value of less than unity would have a negative impact on hybrid form adoption.

\section{Results}

The definitions of the variables used in the model to test hypotheses on the adoption of hybrid forms are presented in Table 2. The dependent variable is equal to 1 if a farmer adopts either relational or forward contracts, which are assumed to be hybrid forms of governance; and it is equal to zero if the spot market is adopted. All individuals of the sample fall into these two categories. In the spot market, farmers negotiate their cattle a number of days, generally a week, before delivery. The price is determined in this negotiation. The identity of the parties is not relevant and the relationships are sporadic, without any commitment to repeating the transaction in the future. Among the hybrid forms, we found the use of the relational contract, where trust between the parties is based upon a long-term relationship. The forward contract is used in transactions that occur over a pre-established period of time, in which the relationships are characterized by regular transaction 
Table 2. Definition of variables.

\begin{tabular}{lll}
\hline Variable & Proxy & Description \\
$\begin{array}{l}\text { Dependent } \\
\text { Asset specificity }\end{array}$ & Feedlot and certification & $\begin{array}{l}\text { Hybrid forms (relational and forward contracts) }=1,=0 \text { spot market } \\
\text { Adoption of feedlot as the production system and SISBOV } \\
\text { certification and }=1,=0 \text { otherwise } \\
\text { Frequency }\end{array}$ \\
$\begin{array}{ll}\text { Uncertainty } \\
\text { Size }\end{array}$ & $\begin{array}{l}\text { Meat processing plant relationship } \\
\text { Purchase by third party }\end{array}$ & $\begin{array}{l}\text { Years of relationship with the meat processing plant } \\
\text { Percentage of purchase of third-party calves for the feedlot } \\
\text { Total number of hectares }\end{array}$ \\
\hline
\end{tabular}

SISBOV = Brazilian System of Identification and Certification of Bovine and Bubaline Origin

volumes, consistency in the quality of the product and by prices based on future quotes on stock exchanges or spot quotes upon delivery of the animals.

Out of a total of 84 cattle farmers in the sample, 60 of them operated exclusively in the spot market. The other 24 cattle farmers operated using hybrid forms of commercialization. Of these, 10 cattle farmers worked exclusively with forward contracts and the other 9 negotiated over half of the volume of their herds through forward contracts and the rest on the spot market. Another three cattle farmers traded exclusively through relational contracts while another two traded using both relational contracts and the spot market.

Table 3 shows the results of the logit model. ${ }^{2}$ The likelihood ratio (LR) was used to test the hypothesis that all the slope coefficients in the logit model are zero. The restricted log likelihood value is -50.2546 . The unrestricted log likelihood value is -32.8578 . The LR test statistics are therefore 34.79 . With four degrees of freedom, the critical value at the $5 \%$ significance level is 14.86 , and so the joint hypothesis that the coefficients on the full set of variables are all zero is rejected.

The interpretation of odds ratios (e $\beta$ ) can be made using the formula $[(e \beta-1) \times 100]$, which shows the change in percentage points in the probability of the dependent variable to be equal to 1 (adoption of hybrid governance) as a response to the change of one unit in the independent variable. The results of the estimated parameters of the model for asset specificity, frequency and uncertainty are in agreement with the theory. These parameters had the

Table 3. Logit model estimation.

\begin{tabular}{|c|c|c|c|c|}
\hline \multicolumn{2}{|l|}{$\begin{array}{l}\text { Number of objects }=84 \\
\mathrm{Chi}^{2}(4)=34.7948\end{array}$} & \multicolumn{3}{|c|}{$\begin{array}{l}\text { Log-likelihood=-32.8578 } \\
\text { Nagelkerke } R^{2}=0.4860\end{array}$} \\
\hline Variables $^{1}$ & Odds ratio & Standard error & Wald statistics & $P$ \\
\hline $\begin{array}{l}\text { Intercept } \\
\text { Asset specificity* }\end{array}$ & 0.4042 & 0.7409 & 1.4950 & 0.2214 \\
\hline $\begin{array}{l}\text { Feedlot and certification* } \\
\text { Frequency }\end{array}$ & 4.4685 & 0.4417 & 11.4889 & 0.0007 \\
\hline $\begin{array}{l}\text { Slaughterhouse relationship } \\
\text { Uncertainty }\end{array}$ & 1.0160 & 0.0455 & 0.1220 & 0.7269 \\
\hline Purchase of third-party & 1.4042 & 0.7683 & 0.1952 & 0.6586 \\
\hline $\begin{array}{l}\text { Size }{ }^{\star \star} \\
\text { Correct prediction: } 79.59 \%\end{array}$ & 1.0001 & 0.0001 & 6.4389 & 0.0112 \\
\hline
\end{tabular}

$1 *=$ significant at $1 \%$ level; ${ }^{* *}=$ significant at $5 \%$ level.

\footnotetext{
${ }^{2}$ Estimations were made using Statistica 10.0.
} 
expected sign. However, only asset specificity, measured by the adoption of feedlot as the production system to fatten cattle and SISBOV certification, was statistically significant at the $1 \%$ level. Thus, hypothesis 1 is accepted. The variable for asset specificity has the greatest impact on the probability that farmers will adopt hybrid governance. The odds of adopting the hybrid structure significantly increases when farmers rear cattle using a feedlot system and adopt the SISBOV certification. In fact, a highly capitalintensive production system requires specific investments, such as facilities and human resources. The time for selling cattle is restricted; otherwise profits could fall. In order to mitigate the uncertainty and price risk associated with these investments, farmers adopt forward contracts. The SISBOV certification also requires specific investments in training and information technology equipment, besides the investment made in learning the certification process and the start-up costs. In order to ensure the premium price payment for traced animals, farmers can include a specific contractual clause. It is a mechanism to ensure the appropriation of quasi-rent arising from the investments made in implementing traceability and obtaining certification. This result corroborates the proposal forwarded by Williamson (1989) in which the high specificity of the assets leads to the adoption of closer forms of coordination. The empirical study of Banterle and Stranieri (2008) revealed that voluntary adoption of traceability labelling system has led to asset specificity increases in the Italian meat chain. As a consequence, vertical agreements among the agents were strengthened. Mora and Menozzi (2005) also observed that the adoption of traceability, fostered by European regulations, narrowed vertical relationships in the Italian beef production chain.

The percentage of animals acquired from third parties for the fattening phase was used as a proxy for uncertainty. This is based on the assumption that cattle farmers that are more dependent on the supply of third parties for their backgrounding cattle for fattening needs are subject to strong fluctuations in the economic viability of their business due to changes in the finished cattle/calf exchange ratio. This type of economic risk is not faced by cattle farmers that internalize part, or all, of backgrounding cattle production. The parameter estimated for this variable was not statistically significant in the logit model. As a result, it was not possible to accept the hypothesis of the alignment of this transaction attribute with the form of governance, considering this variable as a proxy. However, hypothesis 3 cannot be fully rejected. In fact, other considerations regarding uncertainty must be taken into account, for example, the impact of institutional environments of high or low uncertainty with regard to price. It was not possible to carry out this type of evaluation based on the current sample of cattle farmers, since all of the individuals are subject to the same institutional environment. Here, the possible conclusion is that this source of uncertainty is not sufficient to promote hybrid governance in the transactions between meat processing plants and cattle farmers.

The frequency with which the relationship between the parties is established is another transaction attribute. The parameter estimated for this variable was not statistically significant, despite signs indicating the expected effect on the mechanisms of governance adopted. Therefore, hypothesis 2 was also not proven.

Farm area was used as a proxy for size and is statistically significant at a level of $5 \%$. The odds ratio of size shows that adoption of hybrid governance significantly increases when the total area of farms is higher. In fact, for the meat processing plants, establishing contracts with larger cattle farmers improves planning for the slaughter/processing capacity, enabling the purchase of more standardized animals and reducing transaction costs.

\section{Final considerations}

In general, the production of finished cattle in intensive systems, associated with the need for traceability certification for the European market, involves investments in specific assets and, consequently, the need for hybrid forms of coordination that ensure the earning of quasi-rents due to the specificity of the assets. In contrast, there are fewer requirements in the transactions that involve the sale of untraced cattle and production can be carried out in less intensive systems that do not adopt traceability. In this case, the specificity of the assets is lower, making contracts or closer relations between the parties unnecessary, since the cattle farmer has more options for buyers in the market, without running the risk of a loss in value.

From the perspective of the meat processing companies, the need to ensure a certain level of regularity and volume of animals to serve their foreign market makes contractual governance a relatively strategic option. However, to meet the needs of less demanding markets, the purchase of animals on the spot market is perfectly adequate, considering the risks that the meat market offers at the end of the chain.

These results have implications for organizations in the beef industry as well as policy makers in terms of strategies focused on higher quality beef products. Traceability can provide direct production management benefits. It allows for improvements in the whole production chain, as better 
information systems and production controls are adopted. Identification and communication of potential issues becomes more efficient and the costs of recall in the event of food contamination can be reduced.

It was found that the forms of governance employed to coordinate transactions between cattle farmers and meat processing plants are aligned with the principal attribute of governance proposed by Williamson (1985): asset specificity. This indicates that the farmers were able to measure the transaction characteristics and choose more efficient solutions in order to minimize them and ensure the appropriation of part of the gains arising from specific investments.

\section{Acknowledgement}

The research was supported by the Foundation for Research Support of the State of São Paulo, Brazil (FAPESP). The analysis and comments are, however, the authors' responsibility.

\section{References}

Arieira, J.O., C.R. Dias-Arieira and I.C. Gozer, 2007. Análise comparativa de sistemas de produção de gado de corte: pasto rotacionado x confinamento. In: Proceedings of Brazilian Congress of Rural Economics and Sociology, 45, Londrina, PR, Brazilian Society of Economics, Business and Rural Sociology. 1 CD-ROM.

Banterle, A. and S. Stranieri, 2008. Information, labelling, and vertical coordination: an analysis of the Italian meat supply networks. Agribusiness, 24(3): 320-331.

Boger, S., J.E. Hobbs and W.A. Kerr, 2001. Supply chain relationships in the polish pork sector. Supply Chain Management: An International Journal, 6(2): 74-82.

Carrer, M.J., H.M. Souza Filho and M.M.B. Vinholis, 2014. Plural forms of governance in the beef industry: a case study in Brazil. British Food Journal, 116(4): 643-661.

Carrer. M.J., M.M.B. Vinholis, H.M. Souza Filho and F.T. Rosa, 2011. Formas plurais de coordenação das transações na cadeia de carne bovina: um estudo de caso no Brasil. In: Proceedings of Brazilian Congress of Rural Economics and Sociology, 49, Belo Horizonte, MG, Brazilian Society of Economics, Business and Rural Sociology. 1 CD-ROM.

Coase, R.H., 1937. The Nature of the Firm. Economica, 4(16): 386-405.

Correa, E.S., A. Vieira, F.P. Costa and I.M. Cezar, 2000. Sistema semi-intensivo de produção de carne de bovinos nelores no centro-oeste do Brasil. Embrapa Gado de Corte (Documentos, 95), Campo Grande, MS, Brazil. 49 pp.
Fulponi, L., 2006. Private voluntary standards in the food system: the perspective of major food retailers in OECD countries. Food Policy, 31(1): 1-13.

Globerman, S. and R. Schwindt, 1986. The organization of vertically related transactions in the Canadian forest products industries. Journal of Economic Behavior and Organization, 7(2):199-212.

Guo, H. and R.W. Jolly, 2008. Contractual arrangements and enforcement in transition agriculture: theory and evidence from China. Food Policy, 33(6): 570-575.

Halldorsson, A., H. Kotzab, J.H. Mikkola and T. Skjott-Larsen, 2007. Complementary theories to supply chain management. Supply Chain Management: An International Journal, 12(4): 284-296.

Hendrikse, G.W.J., 2003. Governance of chains and networks: a research agenda. Journal on Chain and Network Science, 3(1): $1-6$.

Hobbs, J.E. and L.M. Young, 2000. Closer vertical co-ordination in agri-food supply chains: a conceptual framework and some preliminary evidence. Supply Chain Management: An International Journal, 5(3): 131-142.

Hobbs, J.E., 2004. Information asymmetry and the role of traceability systems. Agribusiness, 20(4): 397-415.

Kariuki, I.M., J. Loy and T. Herzfeld, 2012. Farmgate private standards and price premium: evidence from the GlobalGap scheme in Kenya's french beans marketing. Agribusiness, 28(1): 42-53.

Klein, P.G., 2008. The make-or-buy decisions: lessons from empirical studies. In: Menard, C. and M.M. Shirley (eds.) Handbook of new institutional economics. Springer, Dordrecht, the Netherlands, pp. 435-464.

Krieger, S. and G. Schiefer, 2007. Conception of integrated models for quality management in production chains in the agri-food sector. In: Theuvsen, L., A. Spiller, M. Peupert and G. Jahn (eds.) Quality management in food chains. Wageningen Academic Publishers, Wageningen, the Netherlands, pp. 303-313.

Macher, J.T. and B.D. Richman, 2008. Transaction cost economics: an assessment of empirical research in the social sciences. Business and Politics, 10(1). http://dx.doi.org/10.2202/14693569.1210 .

Martinez, S.W., 2002. A comparison of vertical coordination in the U.S. poultry, egg, and pork industries. Current Issues in Economics of Food Markets, Agriculture Information Bulletin No. 747- 05, U.S. Department of Agriculture, Economic Research Service.

Masten, S.E., 2000. Transaction-cost economics and the organization of agricultural transactions. Industrial Organization, 9: 173-195.

Mello, F.O.T. and L.F.O. Paulillo, 2010. Formas plurais de governança no sistema agroindustrial citrícola paulista. Revista de Economia e Sociologia Rural, 48(1): 135-139.

Menard, C., 2004. The economics of hybrid organizations. Journal of Institutional and Theoretical Economics, 160(3): 345-376. 
Ministério da Agricultura, Pecuária e Abastecimento (MAPA), 2013. Foreign trade statistics provided by the Brazilian Ministry of Agriculture, Livestock and Food Supply, Brasilia, DF, Brazil. Available at: www.agricultura.gov.br/internacional/indicadorese-estatisticas.

Mondelli, M. and D. Zylbersztajn, 2008a. Determinantes dos arranjos contratuais: $\mathrm{O}$ caso da transação produtor-processador de carne bovina no Uruguai. Revista de Economia e Sociologia Rural, 46(3): 831-868.

Mondelli, M. and D. Zylbersztajn, 2008b. Direct-contracting and brokers in the producer-processor transaction: the Uruguayan beef industry case. International Society for New Institutional Economics, $12^{\text {th }}$ Annual Conference at the University of Toronto, June 20-21, 2008.

Mondelli, M.P. and P.G. Klein, 2014. Private equity and asset characteristics: the case of agricultural production. Managerial and Decision Economics, 35(2): 145-160.

Mora, C. and D. Menozzi, 2005. Vertical contractual relations in the Italian beef supply chain. Agribusiness, 21(2): 213-235.

North, D., 1992. Transaction costs, institutions and economic performance. International Center for Economic Growth, San Francisco, CA, USA, 33 pp.

Owens, F.N., Dubeski, P. and Hanson, C.F., 1993. Factors that alter the growth and development of ruminants. Journal of Animal Science, 71(11): 3138-3150.

Pigatto, G., 2001. Determinantes da competitividade da indústria frigorifica de carne bovina do Estado de São Paulo. Ms. dissertation, Federal University of São Carlos, São Carlos, SP, Brazil, $221 \mathrm{pp}$.

Pitelli, M.M., 2004. Sistema agroindustrial brasileiro da carne bovina: análise do impacto das mudanças institucionais europeias sobre a estrutura de governança. Ms. dissertation, University of São Paulo, Piracicaba, SP, Brazil, 160 pp.

Raynaud, E., L. Sauvée and E. Valceschini, 2009. Aligning branding strategies and governance of vertical transactions in agri-food chains. Industrial and Corporate Change, 18(5): 835-868.
Rodrigues, L. and M.A.F.D. Moraes, 2005. Análise das formas de governança utilizadas nos processos de carregamento e transporte de cana de açúcar. In: Proceedings of Brazilian Congress of Rural Economics and Sociology, 43, Brasília, DF, Brazilian Society of Economics, Business and Rural Sociology. 1 CD-ROM.

Souza Filho, H.M., F.T. Rosa and M.M.B. Vinholis, 2010. Análise da competitividade da cadeia produtiva da carne bovina do Estado de São Paulo. Informações Econômicas, 40(3): 16-28.

Trienekens, J. and P. Zuurbier, 2008. Quality and safety standards in the food industry, developments and challenges. International Journal of Production Economics, 113(1): 107-122.

Vinholis, M.M.B., 2001. O desafio da rastreabilidade no mercado brasileiro de carne bovina: um estudo multicaso de frigoríficos exportadores. MSc. dissertation, Federal University of São Carlos, São Carlos, SP, Brazil, 134 pp.

Williamson, O.E., 1985. The economic institutions of capitalism: firms, markets, relational contracting. The Free Press, New York, NY, USA, 450 pp.

Williamson, O.E., 1991. Comparative economic organization: the analysis of discrete structural alternatives. Administrative Science Quarterly, 36: 269-296.

Williamson, OE., 1989. Transaction cost economics. In: Schmalensee, R. and R. Willig (eds.) Handbook of industrial organization. Elsevier, Amsterdam, the Netherlands, pp. 135-182.

Zylbersztajn, D. and C.A.P. Machado Filho, 2003. Competitiveness of meat agri-food chain in Brazil. Supply Chain Management: An International Journal, 8(2): 155-165.

Zylbersztajn, D. and M. Miele, 2005. Stability of contracts in the Brazilian wine industry. Revista de Economia e Sociologia Rural, 43(2): 353-371.

Zylbersztajn, D., 1995. Estruturas de governança e coordenação do agribusiness: uma aplicação da Nova Economia das Instituições. Tese de Livre Docência, University of São Paulo, São Paulo, SP, Brazil, 238 pp.

Zylbersztajn, D., 2005. Papel dos contratos na coordenação agroindustrial: um olhar além dos mercados. Revista de Economia e Sociologia Rural, 43(3): 385-420. 
